\title{
The Development of Mathematics Homework Engagement (MHE) Instrument for Secondary School Students, Malaysia
}

\author{
Murugan Rajoo ${ }^{1} \&$ Arsaythamby Veloo ${ }^{1}$ \\ ${ }^{1}$ School of Education and Modern Languages, University Utara Malaysia, (UUM), Sintok, Kedah, Malaysia \\ Correspondence: Arsaythamby Veloo, School of Education and Modern Language, University Utara Malaysia, \\ Sintok, Kedah, 06010, Malaysia. E-mail: arsay@uum.edu.my
}

Received: March 5, 2015 Accepted: May 3, 2015 Online Published: May 14, 2015

doi:10.5539/res.v7n7p87 URL: http://dx.doi.org/10.5539/res.v7n7p87

\begin{abstract}
The purpose of this study is to develop the instrument of Mathematics Homework Engagement (MHE) for secondary school students in Malaysia. This study also identifies the relationship between the factors of Mathematics Homework Engagement, namely students, teachers, parents andschool management towards mathematics achievement. The MHE has been used to measure the engagement of students, teachers, parents and school administrators in mathematics homework. This instrument was developed from student's focus group interviews and the literature review. The results of the analysis was found that these four factors of MHE item instrument ranged from $54.52 \%$ to $69.38 \%$ of variance related with homework engagement. Croanbach Alpha indicated that the reliability of each factor is reasonable in context of internal consistency which is more than 0.70 . Based on the results of validity and reliability, the instrument remained with 15 items, and states that it is sufficient to measure MHE for secondary school students in Malaysia. Pearson correlation coefficient revealed that, there are positive correlations between the factors towards mathematics achievement except for parent's engagement. In conclusion, this instrument can be used by teachers, counselors, school administration and the Ministry of Education to assess students' understanding of MHE. With such understanding, teachers can arrangebetter mathematics homework for their students.
\end{abstract}

Keywords: validity, reliability, mathematics homework engagement

\section{Introduction}

In the process of teaching and learning, there are many possibilities to enhance and deepen the knowledge of the subject studied. These efforts require some action from four sides, teachers, students, parents and school management. Teachers have the responsibility to be the capital and attract the attention of the students to attend their classes. While for students, attending to the class is the most important action in their own learning process. In additional, parents and school management are providing supports for students to complete their mathematics homework. In order to engage, they should prepare themselves before the lesson begins which is very important.

Homework is a kind of assessment which teachers used to evaluate students understanding of the subject. Research shows that, homework has a significant relationship with achievement in mathematics. In Malaysia, homework is compulsory to be given to students after a lesson was completed based on need of the student (Ministry of Education, 2004). Almost every teacher gives homework to the students after a lesson were completed. Now, the question is how many of the teachers make the homework as a "meaningful homework"? According to Ellsaser (2007), meaningful homework refers to a process whereby the teacher collect, correct and grade the given homework in a certain period of time.

Throughout homework, teacher can create a continue learning process and evaluate the level of understanding of students (Trends in International Mathematics and Science Study, TIMSS, 2011). Results from TIMSS (2011) shown that, Malaysia achievement was dropped from the year 1999 to 2011 compared to Singapore (Mullis, Martin, Foy, \& Arora, 2012). In addition, the Malaysian Education Certificate (MEC), results shown that there is instability of mathematics achievement in our country especially in Sabah state (Ministry of Education, 2013). Furthermore, literature study failed to demonstrate the effectiveness of homework as a teaching tool and criticize about the quantity and quality of homework (Bennett \& Kalish, 2006; Kohn, 2006). 
The purpose behind the need of valid and reliable measure of the source of MHE is the fact that MHE helps identify student's perception of mathematics homework. This paper will include student's perceptions to related homework; examine the support of the school management, parent's support and the support of the teachers towards their students like how they motivate or facilitate their student's weaknesses and strengths.

\section{Literature Review}

Fredericks, Blumenfeld and Paris (2004), define behavioural battle as positive behaviour and involvement in academic, sociable or extracurricular activities; a view of the discipline as relevant to a person's existence and social circumstances and seeing succeeded in the discipline as enhancing a person's social value. Some empirical research regarding behavioural engagement was focused on student conduct and on-task behaviour (Karweit, 1989). A more recent subject was conducted by Gonida, Voulala and Kiosseoglou (2009), among 271 seventh and ninthclass scholarly person discovery behavioural engagement was predicted by student domination of goal predilection. Aspects of behaviours' are sometimes separated into different weighing machine (Ladd, Birch, \& Buhs, 1999). Birch and Ladd (1997), found that behavioural engagement include positive behaviours such as completing homework and complying with school rules. A point to make and which informs this study is that behavioural engagement improves performance and validates positive anticipation about academic abilities. It is also a trade good predictor of student's long term academic achievement (Skinner, Zimmer Gembeck, \& Connell, 1998).

\subsection{Students Engagement in Mathematics Homework}

Homework can be defined as a various task assigned to students given by teachers and to be performed or carry on after school hours. Homework may vary according to purpose, topic, student skills and content. The objectives of homework are to instruct students on how they follow and understand the subject and give them the opportunity to learn and explore creatively (Cooper, Robinson, \& Patall, 2006).

Student engagement in mathematics homework is sometimes negligence and absence but there is an underlying pressure to their ignorance. The impact of homework to student may be difficult to determine with non-participation or attempt to do it so as not to misjudge them to understand their negative behavior. It may differ according to their status in schools, social motivation, family and internal problems that each of them are facing every day. Generalizing their overall class achievement in their output and production may be crucial in the sense that the motivation of one may not be different with another and it shows in their performance (Henderson \& Eren, 2008).

To make homework meaningful it should also be fun and exciting especially for secondary rural communities to engage their friends and family to help them. Supplemental learning or use of basic manuals, books, internet, calculator and other resources should also encourage them to do more. This can also provide positive influence and venue to excitement if they are given access to such resources (Bang, 2012).There are studies showing that the involvement of students in completing homework lead to higher achievement and have a beneficial effect on the learning outcomes for a long time and the development potential of the students (Carini et al., 2006; Kuh, 2009). Besides that, the researchers consistently conclude that the time spent on homework showed a positive correlation with academic achievement for students of secondary schools and tertiary levels (Cooper, 1989; Cooper, Robinson, \& Patall, 2006).

Furthermore, Trautwein et al. (2002) analysed of a series of surveys given to 1,976 high school students and found that although the frequency of mathematics homework a positive impact mathematics achievement, the amount of homework and the time taken to complete the homework had no effect on achievement in mathematics. In additional, most of the research on engagement has foundagood positive relationship between student engagement and achievement (Connell, Spencer, \& Aber, 1994; Finn \& Rock, 1997; Klem \& Connell, 2004).

\subsection{Teachers Engagement in Mathematics Homework}

Teachers and parents are one of the strongest driving forces towards student's motivate ion in high school. They are the key factors that can highly change the students' perception towards achieving higher learning. According to Sullivan (2008), the effect of their involvement can result students to achieve higher grades. Communication between parents and teachers about their programs including their collaboration to the community should provide active comfort and assistance to motivate students.

In a recent study conducted in the rural schools of Sabah, with 10 teachers and 60 students, their healthy engagement shows that in the context of pedagogical strategies, the possibility of positive attitude has been seen. This strategy increases their participation and enlivens their activities inside the classroom (Matanluk, 2014). 
Critically their involvement to seatwork is not questioned but their involvement to assignment or homework is something to think about since they are not present.

Simple homework should be an easy task. If it is memorization students can do it with the usual routine but mathematics is more than memorization (Vatterott, 2009). Homework is getting out of sync within the family today because of busy schedule and different priorities that leave the student with only their resources including books or if they are lucky online tools may be present but not necessarily. The support of the family is what they need in the progression of the students.

Hong, Wan, and Peng (2011) examine the discrepancy between the perception of Chinese students and teachers on mathematics homework behaviour and English. Scales were evaluated homework problems and the reasons for not completing homework. They reported that the assessment of students on homework behaviour is more negative evaluations. Hong et al. (2011) observed that understanding the behaviour of students homework is important. They suggested that to reduce conflict and increase awareness of behavioural homework, the teacher should provide feedback and evaluate homework.

\subsection{Parents Engagement in Mathematics Homework}

Parents engage in a wide variety of engagement strategies, such as providing space and materials for homework; interact with the teacher about homework; monitoring of completion of homework; make rules about when, where or how homework is done; respond to questions about homework and provide feedback; or provide direct instruction towards homework (Hoover-Dempsey, Battiato, Reed, DeJong, \& Jones, 2001). According to theorists of motivation (Grolnick \& Ryan, 1989; Pomerantz, Grolnick, \& Price, 2005) from, parent involvement may have different effects on student achievement, and this effect may vary depending on the characteristics of the students.

Over the years, the research found that the level of family involvement in homework is not significantly related to academic achievement (Balli, Wedman, \& Demo, 1997; Cooper et al., 2000). In fact, a study (Epstein, 1988), suggesting that the involvement of parents in helping students with their homework made a student with lower score achievement. Besides that, family involvement is also important to the development and achievement of the students (Hiatt-Michael, 2010). According to Xu (2009), parental support with homework structure is important for students to complete homework. Students-boys in secondary schools benefit from family involvement. Low achievers get more time when parents help their homework and even returned to the teachers. Primary school students benefit from parental involvement. A meta-analysis 22 samples from 20 studies correlating parent involvement and achievement reveals a positive relationship to school but a negative relationship for secondary school students (Patall, Cooper, \& Robinson, 2008).

Studies using both correlation and experimental showed that students in secondary schools generally do not benefit from parental involvement in homework. Parents need to realize about their children progress and adjust accordingly in their involvement towards the homework process. For example adolescence is a period of attempts to develop some level of independent and autonomous from their parents in many domains (Gutman \& Midgley, 2000).

\subsection{School Management Engagement in Mathematics Homework}

In the efforts of the Malaysian government and the school management to achieve higher mathematics performance, students are constantly given voluminous homework. Although several critics believe that this may not be the answer for improvement, considering that more of the students' assignments, especially in secondary students took to gauge their success. Critics believe that students are bombarded with too much homework. This is proven true by the TIMSS themselves that Malaysian students are given the most numbers of homework. According to KeithRozario.com (2014), about $63 \%$ of students spend at least 45 minutes of their homework in a single subject.School administration must also be vigilant to promote the five approaches to support and sustain their moral. These are a good working environment and management support, the availability of materials, tools and supplies upon implementation of policy; monitoring through encouragement; continuous appreciation and the promotion for school success (Razak, 2013).

School management also has the authority to measure and upgrade the necessary recommendations needed to change the system in mathematics if they feel that there is a necessity to do so. They should be held accountable in the curriculum based factors of studies by providing adequate solutions in their success. Schools in Sabah can work hand-in-hand with local and international organizations to assist these organizations in their studies to advance or include more of technology in their curriculum (Bakar, 2007). 


\subsection{Objectives of the Study}

The objectives of this study are to develop instrument of Mathematics Homework Engagement for secondary school students and to determine the relationship between Mathematics Homework Engagement factors, namely students, teachers, parents and school management towards mathematics achievement.

\section{Methodology}

\subsection{Sample}

This study was conducted in secondary schools in Sabah, Malaysia. The study population consisted of 19,105 grade 10students. Fromthe total population, 9,000 (47.11\%) of boysand 10,105 (52.89\%) of girls who are represent from all secondary school students in the state. However, the sample size of this study were 400 secondary schools' students, 185 (46\%) of malestudents and 215 (54\%) of female students.

\subsection{Instrumentation}

Data for this study were collected with an instrument consisting of 15 items. All the items were developed to measure the factors of MHE. Students were asked to give an opinion on the extent to which they agreed with the statement in the form of a Likert scale of 4 points. The options are 1 (strongly disagree), 2 (disagree), 3 (agree) and 4 (strongly agree). These items provide input about the student's perceptions of Mathematics Homework Engagement of students, teachers, parents and school administrator's factors. The first part of MHE survey consists of 4 items that measure student engagement $(\mathrm{St})$ in mathematics homework. The second part consists of 3 items that assess the engagement of teachers $(\mathrm{Tc})$ in mathematics homework. Whereas, the third part consists of 4 items that measure parental engagement $(\mathrm{Pr})$ in mathematics homework. Finally, the fourth part consists of 4 items that assess the engagement of school administrators $(\mathrm{Sm})$ in mathematics homework. This instrument was developed based on the literature review and focus group interviews of students. There are 7 items developed from focus group interview of students and remaining of 8 items was developed from literature review. Table 1 shows the study of literature for related item.

Table 1. Item development on mathematics homework engagement

\begin{tabular}{lll}
\hline MHE & Items & Referenced \\
\hline \multirow{3}{*}{ Student's Engagement } & St 1 & Xu (2008) \\
& St 2 & Betts (1996) \\
& St 3 & Focus group Interview \\
& St 4 & Focus group Interview \\
\hline \multirow{2}{*}{ Teacher'sEngagement } & Tc1 1 Xu (2008); Hall, Villema\& Burley (1989) \\
& Tc 2 & Focus group Interview \\
& Tc 3 & Focus group interview \\
\hline \multirow{3}{*}{ Parent'sEngagement } & Pr 1 & Hoover-Dempsey (2001) \\
& Pr 2 & Hoover-Dempsey (2001) \\
& Pr 3 & Hoover-Dempsey (2001) \\
& Pr 4 & Focus group interview \\
\hline \multirow{2}{*}{ School Management'sEngagement } & Sm 1 & Focus group interview \\
& Sm 2 3 & Focus group interview \\
& Sm 3 & Razak (2013) \\
\hline Total & 15 & Razak (2013) \\
\hline
\end{tabular}

\subsection{Data Analysis}

SPSS version 21 was applied to validate all thefactors. Additionally, Test Kaiser-Meyer-Olkin (KMO), Bartlett's Sphericity and Cronbach alpha was used. Furthermore, the Pearson coefficient was used to determine relationships between the factors. 


\section{Findings}

\subsection{Student's Engagement in Mathematics Homework}

Student's engagement in Mathematics Homework instrument used by four items as shown in Table 2 together with the results of the extraction method and Promax rotated principal component analysis. The overall KMO for student's engagement in mathematics homework is 0.74 and the Bartlett sphericityis significant. The results displayed that the student's engagement in mathematics homework explains $54.52 \%$ of the total variance with factor loadings ranging from 0.70 to 0.79 and eigenvalue of 2.18 . The results showed that in favor of using instruments of student's engagement in mathematics homework to measure mathematics achievement and factor analysis were considered suitable for use with four items of student's engagement in mathematics homework.

Table 2. Factor loadings for Mathematics homework engagement of student's factor

\begin{tabular}{lc}
\hline Items on Student's Engagement & Factor Loading \\
\hline Mathematics homework helps me to understand the lessons taught by teacher. & 0.79 \\
Doing mathematics homework help me to understand the mathematical content of the study. & 0.78 \\
More time spent doing mathematics homework affect the results of mathematics tests/exams. & 0.74 \\
I believe I became proficient in mathematics if doing all the mathematics homework. & 0.70 \\
\hline
\end{tabular}

\subsection{Teacher's Engagement in Mathematics Homework}

Teacher's engagement in Mathematics Homework instrument measured by three items as shown in Table 3 together with the results of the extraction method and Promax rotated principal component analysis. The overall KMO for teacher's engagement in mathematics homework is 0.70 and the Bartlett sphericity is significant. The results displayed that the teacher's engagement in mathematics homework explains $69.38 \%$ of the total variance with factor loadings ranging from 0.82 to 0.86 and eigenvalue of 2.08 . The results showed that in favor of using instruments of teacher's engagement in mathematics homework to measure mathematics achievement and factor analysis were considered suitable for use with three items of teacher's engagement in mathematics homework.

Table 3. Factor loadings for Mathematics homework engagement of teacher's factor

\begin{tabular}{lc}
\hline Items on Teacher's Engagement & Factor Loading \\
\hline $\begin{array}{l}\text { Mathematics teachers always discuss homework given after returning homeworkbooks that } \\
\text { have been reviewed. }\end{array}$ & 0.86 \\
Mathematics teachers provide sufficient reference source to help complete the homework. & 0.82 \\
Mathematics teachers give grades for homework completion. & 0.82 \\
\hline
\end{tabular}

\subsection{Parent's Engagement in Mathematics Homework}

Parent's engagement in Mathematics Homework instrument measured by four items as shown in Table 4 together with the results of the extraction method and Promax rotated principal component analysis. The overall KMO for participation of parent's engagement in mathematics homework is 0.77 and the Bartlett sphericityis significant. The results displayed that the parent's engagement in mathematics homework explain $62.24 \%$ of the total variance with factor loadings ranging from 0.78 to 0.80 and eigenvalue of 2.49 . The results showed that in favor of using instruments of parent's engagement in mathematics homework to measure mathematics achievement and factor analysis were considered suitable for use with four items of parent's engagement in mathematics homework. 
Table 4. Factor loadings for Mathematics homework engagement of parent's factor

\begin{tabular}{lc}
\hline Items on Parent's Engagement & Factor Loading \\
\hline My mother/father helped to do my mathematics homework. & 0.80 \\
My mother/fatheralways check the mathematics homework. & 0.80 \\
My mother/father meet with mathematicsteacher to discuss about homework. & 0.78 \\
My mother/fatherlove it when I make mathematics homework. & 0.78
\end{tabular}

\subsection{School Management's Engagement in Mathematics Homework}

School management's engagement in Mathematics Homework instrument measured by four items as shown in Table 5 together with the results of the extraction method and Promax rotated principal component analysis. The overall KMO for parent's engagement in mathematics homework is 0.78 and the Bartlett sphericityis significant. The results displayed that the school management's engagement in mathematics homework explain $66.76 \%$ of the total variance with factor loadings ranging from 0.74 to 0.87 and eigenvalue of 2.67 . The results showed that in favor of using instruments of school management's engagement in mathematics homework to measure mathematics achievement and factor analysis were considered suitable for use with four items of school management's engagement in mathematics homework.

Table 5. Factor loadings for Mathematics homework engagement of school management's factor

\begin{tabular}{lc}
\hline Items on School Management's Engagement & Factor Loading \\
\hline School administrators motivate students to complete mathematics homework. & 0.87 \\
$\begin{array}{l}\text { Rewards are given by the school to appreciate the efforts of students who complete } \\
\text { mathematics homework. }\end{array}$ & 0.86 \\
$\begin{array}{l}\text { Support from school administrators can help do mathematics homework. } \\
\text { The school administration has stressed the completion of mathematics homework in school }\end{array}$ & 0.80 \\
assembly. & 0.74 \\
\hline
\end{tabular}

\subsection{Reliability Analysis}

Table 6 displays the results of the analysis of the reliability of the instrument MHE. The Cronbach's alpha value for all four factors was above 0.70 . Besides that, the corrected item of total correlation is more than 0.30 . The findings of the study showed that, the alpha reliability coefficient of all the items are acceptable level.

Table 6. Reliability analysis for Mathematics homework engagement

\begin{tabular}{lcll}
\hline MHE & TotalItem & Corrected Item-Total Correlation & Alpha \\
\hline Student's Engagement & 4 & $0.56,0.40,0.51,0.54$ & 0.71 \\
Teacher's Engagement & 3 & $0.59,0.68,0.60$ & 0.78 \\
Parent's Engagement & 4 & $0.62,0.62,0.60,0.59$ & 0.79 \\
School Management's Engagement & 4 & $0.56,0.74,0.72,0.63$ & 0.83 \\
\hline
\end{tabular}

\subsection{Correlation Analysis}

The relationship between student's engagement, teacher's engagement, parent's engagement and school management's engagement towards mathematics achievement was statistically significant except parent's engagement towards mathematics achievement. Besides that, the relationship between student's engagement to teacher's engagement, student's engagement to school management's engagement, teacher's engagement to parent's engagement, teacher's engagement to school management's engagement and school management's engagement to parent's engagement was statistically significant. On the other hand, the relationship between parent's engagement to mathematics achievement and student's engagement to parent's engagement was 
statistically not significant. Table 7 revealed thecorrelation between MHE factors. In this study, thestrongest correlation is between student's engagement and mathematics achievement $(r=0.59)$ and student's engagement and teacher's engagement $(r=0.63)$. But, school management's engagement tostudent's engagement revealed a poor correlation $(\mathrm{r}=0.27)$.

Table 7. Correlation matrix result for the MHE factors and Mathematics achievement

\begin{tabular}{|c|c|c|c|c|c|}
\hline MHE & (1) & (2) & (3) & $(4)$ & $(5)$ \\
\hline Marks (1) & 1 & & & & \\
\hline Student's Engagement (2) & $0.59 * *$ & 1 & & & \\
\hline Teacher's Engagement (3) & $0.53 * *$ & $0.63 * *$ & 1 & & \\
\hline Parent's Engagement (4) & 0.07 & 0.04 & $0.56 * *$ & 1 & \\
\hline School Management Engagement (5) & $0.36^{* *}$ & $0.27 * *$ & $0.46^{* *}$ & $0.39 * *$ & 1 \\
\hline
\end{tabular}

** Correlation is significant at the 0.01 level (2- tailed)

\section{Discussions}

\subsection{Mathematics Homework Engagement}

According to Kaiser, Meyer, and Olkin the discriminant value showed that student's engagement, teacher's engagement, parent's engagement and school management's engagement are middling (Friel, 2009). The Bartlett sphericity are related for all the factors and it's proved that the factor analysis is suitable (Pett et al., 2003). The factor loadings is considered to be a good identifier of the factor if the loading is 0.70 and this study found that all the items were good identifier (Garson, 2010). Besides that, the corrected item-total correlation of all the items are accepted level as suggested by Hair et al. (2006). Besides that, the Cronbach's alpha of the items in all four factors which is an acceptable reliability value (Nunnally \& Bernstein, 1994). In additional, student's engagement factor, teacher's engagement factor, parent's engagement factor and school management's engagement factor consists of four items, three items, four items and four items respectively. All this items based on factors are sufficient, stable and solid as suggested by Costello and Osborne (2005).

\subsection{Correlation Analysis}

The relationship between student's engagement, teacher's engagement, parent's engagement, and school management's engagement towards mathematics achievement were statisticallysignificant except parent's engagement towards mathematics achievement. The positive relationship between student's engagement towards mathematics achievement was aligned with those reported by Carini et al. (2006), Kuh (2009), Cooper (1989), Cooper, Robinson and Patall (2006), Trautwein et al. (2002), Finn and Rock (1997), and Klem and Connell, (2004). Whereby, teacher's engagement towards mathematics achievement showed a positive relationship as researched by Sullivan (2008). On the other hand, parent's engagement is not significantly related to mathematics achievement. These findings aligned withfindings by Balli, Wedman and Demo (1997), Cooper et al. (2000), and Epstein (1988). Studies supported that students in secondary schools generally do not benefit from parental engagement in homework (Gutman \& Midgley, 2000).

\section{Conclusion}

This instrument consisted of 15 items where validated by items and factors. Based on researcher's observation, it takes around 10 minutes for students to respond to the items. The findings support the evidence of good psychometric properties for the MHE instrument. The exploratory factor analysis indicated that the four factors were adequately reliable and valid. The findings revealed that, there were relationships between MHE factors and mathematics achievement except parent's engagement. This attribute is in line with behavioral engagement whichimproves performance and validates positive anticipation about academic abilities. It is also a trade good predictor of student's long term academic achievement.

\section{References}

Bakar, N. (2007). English Language Activities in Computer Based Learning Environment: A Case Study in ESL Malaysian Classroom. GEMA Online Journal of Language Study, 17(1), 33-49.

Balli, S., Wedman, J., \& Demo, D. (1997). Family Involvement with Middle-Grades Homework. Journal of 
Experimental Education, 66, 31-48.

Bang, H. J. (2012). Promising Homework Practices: Teachers' Perspectives on Making Homework Work for Newcomer Immigrant Students. University of North Carolina Press, 95(2), 3-31.

Bennett, S., \& Kalish, N. (2006). The case against homework: How homework is hurting our children and what we can do about it. New York: Crown.

Betts, J. (1996). The Role of Homework in Improving School Quality (Discussion Paper 96-16). Department of Economics, UCSD. Retrieved from http://citeseerx.ist.psu.edu/viewdoc/download?doi=1 0.1.1.26.6844\&rep=rep1\&type $=$ pdf

Birch, S. H., \& Ladd, G. W. (1997). The teacher-child relationship and children's early school adjustment. Journal of School Psychology, 35, 61-79.

Carini, R. M., Kuh, G. D., \& Klein, S. P. (2006). Student Engagement and Student Learning: Testing the Linkages. Research in Higher Education, 47, 1-32. http://dx.doi.org/10.1007/s11162-005-8150-9

Connell, J., Spencer, M., \& Aber, J. (1994). Educational risk and resilience in African-Americanyouth: Context, self, action, and outcomes in school. Child Development, 65(2), 493-506.

Cooper, H. (1989). Homework. White Plains, New York: Longman.

Cooper, H., Lindsay, J., \& Nye, B. (2000). Homework in the Home: How Student, Family And Parenting-Style Differences Relate To Homework Process. Contemporary Educational Psychology, 25,464-487.

Cooper, H., Robinson, J. C., \& Patall, E. A. (2006). Does homework improve academicachievement? A synthesis of research, 1987-2003. Review of Educational Research, 76, 1-62.

Costello, A. B., \& Osborne, J. W. (2005). Best practices inexploratory factor analysis: four recommendations forgetting the most from your analysis. Practical Assessment. Research \& Evaluation, 10, 1-9. Retrieved March 5, 2013, from http://pareonline.net/getvn.asp?v=10\&n=7

Ellsasser, C. (2007). Do the math: Redesigning homework to create more time for learning. Encounter, 20 , $20-24$.

Epstein, J. (1988). Sample clinical summaries: Using surveys of teachers and parents to plan projects to improve parent involvement (Parent involvement series, report p. 83). Baltimore: Johns Hopkins University, Center for Research on Elementary and Middle Schools.

Finn, J., \& Rock, D. (1997). Academic success among students at risk for school failure. Journal of Applied Psychology, 82(2), 221-234. http://dx.doi.org/10.1037/0021-9010.82.2.221

Fredericks, J. A., Blumenfeld, P. C., \& Paris, A. H. (2004). School engagement: Potential of the concept, state of the evidence. Review of Educational Research, 74, 59-109.

Friel, C. M. (2009). Notes on Factor Analysis. Criminal Justice Centre, Sam Houston State University. Retrieved from http://www.bama.ua.edu/ jcsenkbeil/gy523/Factor\%20 Analysis.pdf

Garson, D. (2010, February 11). Factor analysis. Retrieved March 5, 2013 from http://faculty.chass.ncsu. edu/garson/PA765/factor.html

Gonida, E. N., Voulala, K., \& Kiosseoglou, G. (2009). Students' achievement goalorientations andtheir behavioral and emotional engagement: Co-examining the role of perceived school goal structures and parent goals during adolescence. Learning \& Individual Differences, 19(1), 53-60.

Grolnick, W. S., \& Ryan, R. M. (1989). Parent Styles Associated with Children's Self-Regulation and Competence in Schools. Journal of Educational Psychology, 81, 143-154.

Gutman, L. M., \& Midgley, C. (2000). The Role of Protective Factors in Supporting the Academic Achievement of Poor African American Students during the Middle School Transition. Journal of Youth and Adolescence, 20, 223-248. http://dx.doi.org/0047-2891/00/0400-0223

Hair, J. F., Black, W. C., Babin, B. J., Anderson, R. E., \& Tatham, R. L. (2006). Multivariate Data Analysis (6th ed.). New Jersey: Pearson Prentice Hall.

Hall, B. W., Villeme, M. G., \& Burley, W. W. (1989). Teachers' attributions for students' academic success and failure and the relationship to teaching level and teacher feedback practices. Contemporary Educational Psychology, 14, 133-144.

Henderson, D., \& Eren, O. (2008). The impact of homework on student achievement. The Econometrics Journal, 11(2), 326-348. Retrieved from http://onlinelibrary.wiley.com/doi/10.1111/j.1368-423X.2008.00244.X/ 
Hiatt-Michael, D. (2010). Promising Practices to Support Family Involvement in Schools. US: Information Age Publishing.

Hong, E., Wan, M., \& Peng, Y. (2011). Discrepancies between Students' and Teachers' Perceptions of Homework. Journal of Advanced Academics, 22, 280-308.

Hoover-Dempsey, K. V. et al. (2001). Parental involvement in homework. Educational Psychologist, 36, $195-209$. Retrieved from http:/www.tandfonline.com/doi/abs/10.1207/S15326985EP3603_5\#.VMu5KmiUezU

Karweit, N. (1989). Time and Learning: A Review. In R. Slavin (Ed.), School and classroomorganization. Hilsdale, NJ: Erlbaum.

KeithRozario.com (2014). Science in Malaysia \#1 myth Homework. Retrieved from http:/www.keithrozario.com/2012/12/science-malaysia-homework-myth.html [13 May 2014]

Klem, A., \& Connell, J. (2004). Relationships matter: Linking teacher support to student engagement and achievement. Journal of School Health, 74(7), 262-273.

Kuh, G. D. (2009). The National Survey of Student Engagement: Conceptual and Empirical Foundations. New Directions for Institutional Research, 141, 5-20. http://dx.doi.org/10.1002/ir.283

Malaysian Ministry of Education. (2004). General Employment Guidelines of Homework to Students. Pekeling Ikhtisas Malaysian Ministry of Education.

Malaysian Ministry of Education. (2013). Analysis of Malaysian Examination Certificate. Examination Board of Malaysian Ministry of Education.

Kohn, A. (2006). The homework myth: Why our kids get too much of a bad thing. Cambridge, MA: De Capo Lifelong Books.

Ladd, G. W., Birch, S. H., \& Buhs, E. S. (1999). Children's social and scholastic lives in kindergarten: Related spheres of influence? Child Development, 70(6), 1373-1400. http://dx.doi.org/10.1111/1467-8624.00101

Matanluk, P. (2014). Procedia Social and Behavior. Science Direct Journal, 90(10).

Mullis, I. V. S., Martin, M. O., Foy, P., \& Arora, A. (2012). TIMSS 2011 International results in mathematics. Chestnut Hill, MA: Boston College.

Nunnally, J., \& Bernstein, I. H. (1994). Psychometric Theory. New York: McGraw-Hill.

Patall, A. E., Cooper, H., \& Robinson, J. C. (2008). Parent involvement in homework: A research synthesis. Review of Educational Research, 78, 1039-1011. http://dx.doi.org/10.3102/0034654308325185

Pett, M., Lackey, N., \& Sullivan, J. (2003). Making sense offactor analysis. Thousand Oaks: Sage Publications, Inc.

Pomerantz, E. M., Grolnick, W. S., \& Price, C. A. (2005). The role of parents in how children approach achievement: A dynamic process perspective. In A. Elliot, \& C. W. Dweck (Eds.), Handbook of competence and motivation (pp. 259-278). New York: Guilford Press.

Razak, A. Z. A. (2013). Learning about teachers' resilience: perceptions, challenges and strategies of policy implementation in two secondary schools in Malaysia. Retrieved from http://muir.massey.ac.nz/handle/10179/4266 [14 May 2014]

Skinner, E. A., Zimmer-Gembeck, M. J., \& Connell, J. P. (1998). Individual differences and thedevelopment of perceived control. Monographs of the Society for Research in Child Development No. 254, 63(2-3).

Sullivan, F. (2008). The Effects of Parental Involvement with Mathematics Homework on Early Elementary and Junior High School Students. New York: Proquest.

Trautwein, U., Köller, O., Schmitz, B., \& Baumert, J. (2002). Do homework assignments enhance achievement? A multilevel analysis in 7th-grade mathematics. Contemporary Educational Psychology, 27, $26-50$. http://dx.doi.org/10.1006/ceps.2001.1084

Vatterott, C. (2009). Rethinking Homework Best Practices That Support Diverse Needs (pp. 1-3). Alexandria VA: ASCD.

$\mathrm{Xu}$, J. (2008). Models of Secondary School Students Interest in Homework: A Multi-Level Analysis. American Educational Analysis Journal, 45(4), 1180-1205. http://dx.doi.org/10.3102/0002831208323276

$\mathrm{Xu}$, J. (2009). Homework management reported by secondary school students. A multilevelanalysis. In R. Deslandes (Ed.), International perspectives on student outcomes and homework family-school-community 
partnerships. London: Routledge.

\section{Copyrights}

Copyright for this article is retained by the author(s), with first publication rights granted to the journal.

This is an open-access article distributed under the terms and conditions of the Creative Commons Attribution license (http://creativecommons.org/licenses/by/3.0/). 